\title{
GAMBARAN KESEGARAN JASMANI PADA REMAJA LAKI-LAKI DENGAN ANEMIA
}

\author{
Dewi Permaesih ${ }^{1}$ dan Yuniar Rosmalina ${ }^{1}$ \\ ${ }^{1}$ Pusat Penelitian dan Pengembangan Gizi, Bogor, Badan Litbang,DepKes RI
}

\begin{abstract}
Physical fitness is needed for daily activities. The level of physical fitness could be recognized through many measurement. Many factors influence the level of physical activity, include anemia. The purpose of the study is to find physical fitness level among anemia adult. A cross sectional design was apllied in this study. This study site took place at Pondok Pesantren in Bogor,West Java. Sample were student who stay in Pondok Pesantren. Data on anemia were identified from result of hemoglobin determination by cyanmethemoglobin method. Physical fitness score measured from cardiovascular endurancece,muscle strength, flexibility, muscle endurance and body composition. Univariate and bivariate were applied in this analysis. The result showed that level of physical fitness index the sample $98,4 \%$ in moderate level. The result biavariate analysisi showed relation between age and physical fitness index.
\end{abstract}

Keywords: anemia, physical fitness, teenage

\section{PENDAHULUAN}

$\mathrm{K}$ esegaran jasmani adalah kemampuan untuk melakukan kegiatan atau pekerjaan sehari-hari dan adapatasi terhadap pembebanan fisik tanpa menimbulkan kelelahan berlebihan dan masih mempunyai tenaga untuk menikmati waktu senggang maupun pekerjaan mendadak serta terbebas dari penyakit. Makin tinggi kemampuan fisik seseorang, makin mampu mengatasi beban kerja yang diberikan atau dengan kata lain kemampuan produktivitasnya makin tinggi $(1,2,3)$.

Tingkat kesegaran jasmani dipengaruhi oleh banyak faktor, antara lain gaya hidup yang meliputi konsumsi makanan, pola aktifitas dan kebiasaan merokok. Faktor lain adalah anemia yaitu kondisi dimana kadar hemoglobin dalam darah berada pada nilai dibawah nilai normal ${ }^{(4)}$. Hemoglobin berperan sebagai transportasi oksigen untuk beredar keseluruh tubuh. Bila kadar hemoglobin dalam darah kurang tentu akan berpengaruh pada suplai oksigen tubuh, yang akhirnya akan menjadi tubuh cepat lelah dan tentunya tingkat kesegaran jasmaninya menjadi berkurang.

Kesegaran jasmani seseorang dapat diukur secara kuantitatif. Komponen kesegaran jasmani yang dapat diukur adalah ketahanan kardiovaskular, kekuatan otot, kelenturan otot, ketahanan otot dan komposisi tubuh. Skor atau tingkat ketahanan jasmani seseorang dapat diukur dengan melalui serangkaian pemeriksaan fisik yang berhubungan dengan komponen tersebut dengan menggunakan metoda dan peralatan yang sesuai dengan tujuan pengukuran ${ }^{(1)}$.

Sampai saat ini belum banyak informasi tentang kesegaran jasmani pada remaja khususnya penderita anemia. Padahal anemia dapat mempengaruhi kesegaran jasmani yang merupakan salah satu tolok ukur kualitas fisik. Tulisan ini mengemukan informasi dari hasil pengolahan data dari informasi yang tersedia tentang berbagai komponen kesegaran gizi pada remaja penderita anemia.

\section{BAHAN DAN CARA}

Analisis ini menggunakan data dasar studi "Pengaruh olahraga aerobik dan 
pemberian pil besi terhadap status nesi dan tingkat kesegaran jasmani pada remaja" tahun 2003. Jumlah sampel remaja anemia dan yang mempunyai data lengkap untuk 4 pengukuran komponen kesegaran jasmani berjumlah 125 orang.

Penentuan kadar hemoglobin menggunakan metode Cyanmethemoglobin dengan nilai batas untuk anemia yang digunakan menurut $\mathrm{WHO}, 2001^{(4)}$ adalah untuk umur $5-11$ tahun $<11,5 \mathrm{~g} / \mathrm{L}, 11-14$ tahun $<12 \mathrm{~g} / \mathrm{L}$, remaja diatas 15 tahun untuk anak perempuan $<12 \mathrm{~g} / \mathrm{L}$ dan laki-laki 13 $\mathrm{g} / \mathrm{L}$. Indeks Massa Tubuh (IMT) dihitung berdasarkan perhitungan berat badan dalam kilogram dibagi tinggi badan dalam meter kwadrat $\left(\mathrm{kg} / \mathrm{m}^{2}\right)$, dari hasil pengukuran digunakan klasifikasi menurut WHO 2001(5). Penimbangam berat badan menggunakan timbangan Seca dengan ketelitian 0,1 kg dan pengukuran tinggi badan menggunakan alat pengukur tinggi badaj Microtoise dengan ketelitian $0,1 \mathrm{~cm}$.

Tingkat kesegaran jasmani didasarkan dari penjumlahan skor hasil penilaian empat komponen yaitu: 1) Ketahanan kardiovaskular dengan test lari jarak 2400 meter. Penilaian didasarkan pada lamanya waktu tempuh yang diperlukan sejak mulai berlari hingga menyelesaikan jarak $2400 \mathrm{~m}$ dan diberik skor 5 bila katagori baik sekali. 2) Kekuatan statik otot ditentukan dengan menggunakan alat dinamometer genggam dan "beg and leg dynamometer". Perhitungan kekuatan statik dilakukan dengan penjumlahan semua hasil pengukuran kekuatan otot dibagi dengan berat badan. Hasil perhitungan dibandingkan dengan tabel yang berskala 1 - 5 dengan skala 5 terbesar yang berarti kekuatan statik ototnya kuat sekali. 3) Kelenturan otot ditentukan dengan metoda "sit and reach", penentuan skor didasarkan pada hasil kemampuan sampel untuk menjangkau sejauh mungkin dalam posisi duduk. Hasil yang dicatat adalah angka skala yang dapat dicapai oleh kedua ujung jari dalam $2 \mathrm{x}$ usaha. Penentuan skor dibandingkan dengan tabel dengan 5 skala. 4) Komposisi tubuh digambarkan dengan berat badan tanpa lemak dan berat lemak. Berat lemak dinyatakan dalam prosentasenya terhadap berat badan total. Persen lemak tubuh dihitung dengan rumus: Specific Gravity (sp.gr) yakni: Persentase lemak $=(5,548$ : sp.gr - 5.044) x 100\%. Specific Gravity 1.0909 - $(0,0101 \times$ tricep $+0,0090 x$ subscapula). Hasil pada perhitungan inipun dibandingkan dengan tabel untuk mendapatkan skor kesegaran jasmani. Tabel komponen kesegaran jasmani memberi nilai skor untuk menentukan tingkat kesegaran jasmani: Baik sekali dengan skor 5 , baik dengan skor 4, cukup dengan skor 3, lebih dengan skor 2 dan 1 untuk kurang dan gemuk. Indeks kesegaran jasmani dihitung dengan menjumlahkan semua nilai skor tiap komponen kesegaran jasmani kemudian dibagi jumlah komponen yang diukur. Selanjutnya indeks kesegaran jasmani yang dihasilkan diklasifikasikan sebagi berikut: $\leq$ 2 termasuk kurang, 2,1 - 3,9 termasuk cukup dan $>3,9$ adalah baik $^{(1)}$.

Analisis univariat dilakukan untuk mendeskripsikan seluruh variabel yang dianalisis. Analisis bivariat regresi logistik sederhana dilakukan untuk melihat hubungan 2 variabel yang secara teori saling berhubungan.

\section{HASIL}

Telah dilakukan pengukuran kesegaran jasmani pada 125 remaja laki-laki dengan anemia dengan rata-rata umur 15,21 \pm 1.6 tahun. Nilai rata-rata kadar hemoglobin pada sampel anemia adalah sebesar 11,5 \pm 0.99 $\mathrm{g} / \mathrm{L}$ dengan rentang nilai $7.7 \mathrm{~g} / \mathrm{L}$ hingga 11.8 $\mathrm{g} / \mathrm{L}$, sedangkan distribusi menurut batasan WHO disajikan pada tabel 1 berikut. 
Tabel 1

Gambaran rata-rata kadar hemoglobin menurut kelompok umur

\begin{tabular}{|l|c|c|c|}
\hline Kelompok umur & $\mathrm{n}$ & Rata-rata $\mathrm{Hb}(\mathrm{g} / \mathrm{d}) \pm \mathrm{SD}$ & Nilai rentang \\
\hline $11-14$ tahun & 41 & $10,94 \pm 0,96$ & $7,7-11,9 \mathrm{~g} / \mathrm{L}$ \\
$>15$ tahun & 84 & $11,8 \pm 0.89$ & $9,2-12,8 \mathrm{~g} / \mathrm{L}$ \\
\hline Total & 125 & $11,58 \pm 9,9$ & $7.7-12.8 \mathrm{~g} / \mathrm{L}$ \\
\hline
\end{tabular}

Dari tabel 1 mendapatkan sampel santri dengan kadar hemoglobin yang cukup rendah yaitu $7.7 \mathrm{~g} / \mathrm{L}$. Kondisi ini perlu mendapat perhatian dengan cara antara lain memperbaiki pola konsumsi makan, menghilangkan faktor infeksi kecacingan serta pemberian pil besi secara teratur.

Data kesegaran jasmani yang dikumpulkan didasarkan pada 5 komponen pengukuran, namun yang digunakan 4 komponen, karena hasil pengukuran ketahanan otot dengan melakukan test "push up" dan "sit up" masing-masing selama 60 detik tidak dapat dilakukan dengan baik dan posisi benar oleh sampel. Karena itu komponen pengukuran ini tidak dimasukan dalam perhitungan, karena data yang dikumpulkan tidak cukup valid. Hal ini tidak mempengaruhi pada perhitungan, karena perhitungan didasarkan pada jumlah komponen pengukuran. Jumlah minmal komponen pengukuran adalah 4 komponen.

Distribusi hasil perhitungan untuk setiap komponen disajikan dalam tabel 2 berikut:

Tabel 2

Distribusi hasil pengukuran Komponen Kesegaran Jasmani

\begin{tabular}{|l|c|c|c|c|c|c|c|c|c|c|}
\hline \multirow{2}{*}{\begin{tabular}{c} 
Komponen kesegaran \\
\multicolumn{1}{c|}{ jasmani }
\end{tabular}} & \multicolumn{2}{|c|}{$\begin{array}{c}\text { Baiksekali } \\
(5)\end{array}$} & \multicolumn{2}{c|}{$\begin{array}{c}\text { Baik } \\
(4)\end{array}$} & \multicolumn{2}{c|}{$\begin{array}{c}\text { Sedang } \\
(3)\end{array}$} & \multicolumn{2}{c|}{$\begin{array}{c}\text { Kurang } \\
(2)\end{array}$} & \multicolumn{2}{c|}{$\begin{array}{c}\text { Kurang } \\
\text { sekali (1) }\end{array}$} \\
\cline { 2 - 12 } & $\mathrm{n}$ & $\%$ & $\mathrm{n}$ & $\%$ & $\mathrm{n}$ & $\%$ & $\mathrm{n}$ & $\%$ & $\mathrm{n}$ & $\%$ \\
\hline Ketahanan kardiovaskular & - & - & - & - & 3 & 2,4 & 81 & 64,8 & 41 & 32,8 \\
\hline Kekuatan otot & - & - & - & - & - & - & 1 & 0,8 & 124 & 99,2 \\
\hline Kelenturan tubuh & 103 & 82,4 & 20 & 16 & 2 & 1,6 & - & - & - & - \\
\hline Komposisi tubuh & 113 & 90,4 & 7 & 5,6 & - & - & - & - & 5 & 4 \\
\hline
\end{tabular}

Tabel 2 menunjukkan hasil pengukuran setiap komponen tersebar pada setiap katagori. Hasil pengukuran pada ketahanan kardiovaskular dan kekuatan otot tidak mendapatkan sampel dalam katagori baik sekali dan baik. Sebanyak $64,8 \%$ sampel hanya mempunyai ketahanan kardiovaskular sedang, sisanya berada pada katagori kurang sekali. Pengukuran pada komponen kekuatan otot mendapatkan katagori yang kurang sekali sebanyak $99,2 \%$.

Persentase tertinggi $(90,4 \%)$ untuk katagori baik ditemukan pada komponen komposisi tubuh. Komposisi tubuh menggambarkan persen lemak terhadap berat badan artinya sample remaja santri ini kondisi tubuhnya baik, mereka tidak kurus maupun gemuk. Persentase tinggi lainnya adalah pada komponen kelenturan tubuh, ditemukan sebanyak $82,4 \%$ sample yang kelententuran tubuhnya baik sekali dan $16 \%$ baik. Sampel berada pada usia remaja di mana tubuh masih mempunyai kelenturan yang baik.

Nilai rata-rata untuk setiap komponen pengukuran dapat dilihat pada Tabel 3 .

Tabel 3 
Hasil pengukuran tiap Komponen Kesegaran jasmani

\begin{tabular}{|l|c|c|c|}
\hline \multicolumn{1}{|c|}{ Komponen kesegaran jasmani } & Nilai rata-rata & Nilai rentang & Nilai baik \\
\hline Ketahanankardiovaskular (menit) & $14,9 \pm 2,2$ & $11,31-23,5$ & $<8,37$ \\
Kekuatan otot (kg BB) & $3,1 \pm 0,6$ & $1,4-4,8$ & $>7,5$ \\
Kelenturan tubuh (cm) & $25,5 \pm 7,1$ & $9,8-42$ & $>19$ \\
Komposisi tubuh (\%) & $7,9 \pm 2,6$ & $4,7-29,5$ & $5-10$ \\
\hline
\end{tabular}

Tabel 3 menunjukkan rentang nilai yang cukup tinggi untuk komponen pengukuran ketahanan kardiovaskular diperlukan waktu antara n 11,31 menit hingga 23,5 menit untuk menyelesaikan jarak lari 2400 meter dan nilai tersebut maupun nilai rata-rata sampel jauh dibawah nilai untuk katagori baik yaitu waktu tempuh selama $<8,37$ menit.

Hasil pengukuran kekuatan otot menunjukkan rentang yang tidak terlalu lebar, antara 1,4 hingga 4,8 kg Berat Badan. Hal ini menunjukkan kekuatan otot dari setiap sampel tidak jauh berbeda. Dari nilai rata-rata yang dihasilkan menunjukkan jauh dibawah nilai untuk katagori baik.

Hasil pengukuran kelenturan tubuh menunjukkan hasil yang lebih, nilai rata- ratanya berada diatas nilai untuk katagori baik. Rentang nilai pada kelenturan tubuh cuku lebar antara 9,8 hingga $42 \mathrm{~cm}$. Dari keempat komponen pengukuran, komponen komposisi tubuh mendapatkan hasil pengkatagorian dengan katagori baik yang cukup tinggi dengan nilai rata-rata berada antara batas nilai baik.

Tingkat kesegaran jasmani merupakan hasil penjumlahan seluruh skor komponen kesegaran jasman yang diukur, kemudian dibagi dengan jumlah komponen pengukuran yang dalam analisis ini digunakan 4 komponen.

Hasil perhitungan untuk penentuan tingkat kesegaran jasmani disajikan pada tabel 4 berikut:

Tabel 4

Distribusi tingkat kesegaran jasmani

\begin{tabular}{|l|c|c|}
\hline Indeks Kesegaran Jasmani & $\mathrm{n}$ & $\%$ \\
\hline Kurang & 2 & 1,6 \\
\hline Cukup & 123 & 98,4 \\
\hline
\end{tabular}

Tabel 4 menunjukkan hampir semua subyek mempunyai tingkat kesegaran jasmani dalam katagori sedang. Kesegaran jasmani dapaat ditingkatkan lebih baik dengan melalui latihan teratur yang dapat dilakukan sambil melaksanakan tugas sehari-hari seperti misalnya untuk meningkatkan kekuatan otot dapat ditingkatkan dengan latihan beban yang dapat digantikan dengan menimba air. Untuk ketahanan kardiovaskular dengan berlari setiap hari. Atau dapat juga dilakukan di sekolah melalui program Pendidikan Jasmani antara lain dengan berolahraga. Didalam pendidikan jasmani atau cabang olahraga tertentu merupakan alat untuk mendidik dan meningkatkan ketrampilan fisik, motorik, ketrampilan berpikir dan 
Gizi Indon 2004,27(2):88-93 Gambaran kesegaran jasmani Dewi Permaesih dan Yuniar

memecahkan masalah termasuk ketrampilan emosional dan sosial.

Status gizi subyek dihasilkan dengan menghitung Indeks Massa Tubuh, disajikan pada tabel 5 . mengukur tinggi badan dan berat badan dan

Tabel 5

Hasil pengukuran antropometri dan IMT remaja santri

\begin{tabular}{|l|c|c|}
\hline Pengukuran & Nilai rata-rata & Nilai rentang \\
\hline Tinggi badan $(\mathrm{cm})$ & $154,9 \pm 9,6$ & $132,5-178,9$ \\
Berat badan $(\mathrm{kg})$ & $44,4 \pm 8,7$ & $26,9-63,9$ \\
Indeks Massa Tubuh & $18,3 \pm 2,1$ & $14,3-26,8$ \\
\hline
\end{tabular}

Rentang nilai yang cukup lebar dikarenakan rentang umur sample yang lebar dan sample berada pada masa pertumbuhan cepat.

Secara teori dapat dijelaskan kesegaranjasmani dapat ditingkat dengan melakukan aktifitas dan olahraga yang benar dan teratur (9) selain itu juga ketahanan dan kekutan yang merupakan komponen kesegaran jasmani pada usia remaja ini masih terus akan meningkat sampai usia 24 tahun, sedangkan umur sampel pada analisis ini masih dibawah umur 24 tahun yang berarti masih dalam kondisi yang dapat diubah. Untuk melihat kecendrungan umur dan indeks kesegaran jasmani dilakukan analisis bivariat. Hasil analisis dapat dilihat pada gambar berikut:

\section{umur}

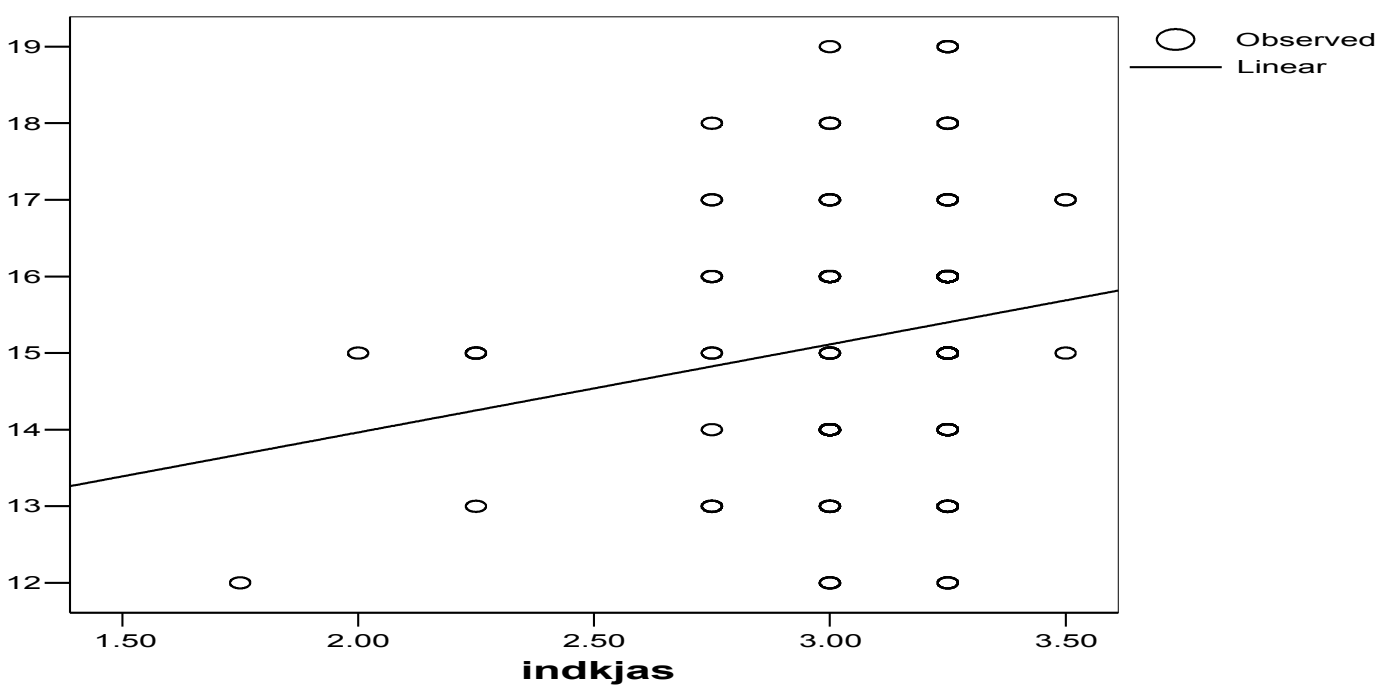

Gambar 1 
Hubungan umur dan indeks kesegaran jasmani.

Gambar 1 menunjukkan semakin tinggi umur semakin tinggi indeks kesegaran jasmani yang dapat dicapai. Karena itu perlu dilakukan pembinaan dan pelatihan yang benar dan teratur agar tubuh dapat mencapai kesegaran jasmani yang optimal.

\section{BAHASAN}

Tingkat kesegaran jasmani dengan status ketahanan kardiovaskular kurang dan kurang sekali ditemukan pada $97 \%$ sampel, kondisi ini lebih buruk bila dibandingkan dengan hasil penelitian yang dilakukan di Bandung pada tahun 1999 pada remaja anak sekolah Sekolah Menengah Umum, pada penelitian ini dilakukan pengukuran ketahanan kardiavaskular dengan menggunakan sepeda statis, namun prinsip pengukurannya sama dengan pengukuran menggunakan lari dengan jarak tempuh 2400 meter. Hasil penelitian mendapatkan sebanyak $88 \%$ katagori sedang dan 6,4\% katagori baik (6). Perbedaan ini dapat disebabkan karena sampel pada analisis ini adalah sampel dengan status anemia. Karena itu perlu adanya upaya peningkatan ketahanan kardivaskular antara lain dengan latihan yang berhubungan dengan ketahanan kardiovaskular tentunya juga perlu disertai dengan pemberian pil besi untuk penanggulangan anemia. Ketahanan kardiovaskular merupakan komponen terpenting dalam kesegaran jasmani.

Yang perlu juga ditingkatkan adalah kekuatan otot. Sampel berada pada usia remaja, dimana seharusnya kekuatan otot harus lebih besar dari nilai yang dihasilkan pada pemeriksaan ini. Kekuatan otot ratarata pada sampel analisis ini lebih rendah bila dibandingkan dengan hasil pengukuran kekuatan otot pada remaja di Bandung yaitu sebesar 4,97 $\pm 1,5 \mathrm{~kg}$ BB dibandingkan dengan $3,1 \pm 0,6 \mathrm{~kg} \mathrm{BB}$. Kekuatan otot dapat ditingkatkan dengan latihan yang teratur.

\section{KESIMPULAN}

Dari hasil analisis data yang dilakukan dapat disimpulkan bahwa indeks kesegaran jasmani pada responden yang terlibat dalam analisis ini berada dalam klasifikasi sedang.

\section{UCAPAN TERIMA KASIH}

Ucapan terimakasih kepada para pengurus Pondok Pesantren yang telah memberi kesempatan pada peneliti untuk melakukan pengumpulan data dan juga telah membantu dalam pelaksanaan pengumpulan data. Ucapan terimakasih juga disampaikan kepada dr Dangsina Moeloek yang banyak memberi masukan dalam pelaksanaan pengukuran komponen kesegaran jasmani, dr Reviana, dr Effendi Rustan dan dr Bona Simanungkalit yang telah membantu dalam pemeriksaan kesehatan sampel. Kepada teman-teman litkayasa yang telah banyak membantu dalam pelaksanaan pengukuran.

\section{RUJUKAN}

1. Departemen Kesehatan (1994). Pedoman Pengukuran Kesegaran Jasmani. Jakarta.

2. Marley,WP (1982). Health and Physical Fitness:Taking Charge of Your Health. Saunders College Publishing. Philadelphia. (162-163)

3. Departemen Kesehatan (1987). Petunjuk Tehnis Kesehatan Olahraga. Bagian Pertama. Jakarta.

4. Unicef/UNU/WHO (2001). Iron deficiency Anemia. Assessment, Prevention and Control. A Guide for Programme Managers.

5. WHO. Technical Report Series 854. 1995. Physical Status: The Use and Interpretation of Antropometry. Report of WHO Expert Committee.

6. Permaesih, D.dkk (2002).Cara praktis pendugaan tingkat kesegaran jasmani. Bulletin Penelitian Kesehatan, Vol. 29 no 29. 
Gizi Indon 2004,27(2):88-93

7. Moeloek, D (1984). Dasar Fisiologi Kesegaran Jasmani dan Latihan Fisik.

Dalam Kesehatan dan Olahraga.
Moeloek, D \& Tjokronegoro (eds). Balai Penerbit FKUI. 